Zbigniew Treppa ${ }^{1}$

Uniwersytet Gdański

\title{
O zbieżnościach przekazów w objawieniach siostry Faustyny Kowalskiej i matki Eugenii Elisabetty Ravasio
}

Ad maiorem Dei gloriam

Jezus Chrystus, ukazując się św. Faustynie i przekazując jej orędzie miłosierdzia Bożego, uczynił to za pomocą słów oraz obrazu. Patrząc z perspektywy teologicznej, jednym z najbardziej charakterystycznych rysów tego objawienia jest uwidocznienie subtelnych niuansów Bożej Miłości. Doświadczenie mistyczne, które w tym artykule zostanie skonfrontowane z wizjami s. Faustyny, ujawnia nie mniej zniuansowaną paletę barw Bożych przymiotów. Mowa jest o wizjach, których doświadczała włoska zakonnica, m. Eugenia Elisabetta Ravasio (w czasie kiedy trwały objawienia, m. Eugenia była jedynie nowicjuszką). W przypadku tych objawień jednym z najbardziej charakterystycznych rysów jest to, że opierają się one również na przekazie werbalno-wizualnym. Znaczące

1 Dr hab. Zbigniew Treppa, prof. Uniwersytetu Gdańskiego, kierownik Zakładu Antropologii Obrazu, członek Polskiego Towarzystwa Teologicznego, Polskiego Centrum Syndonologicznego oraz zespołu eksperckiego w Narodowym Centrum Kultury. Prowadzi badania w zakresie teologii wizualnej i mistagogii obrazu. zbigniewtreppa@icloud.com. 
jest, że m. Eugenia przekazała treści orędzia Boga Ojca², co jest faktem bezprecedensowym w całej historii objawień prywatnych.

Jak się wydaje, dotąd nie podejmowano analiz porównawczych treści przekazów pochodzących z obu wizji. Tymczasem ich treść zawiera zastanawiające zbieżności, co w połączeniu ze świadomością, że objawienia te są szczególnym przykładem połączenia poznania pojęciowego z poznaniem obrazowym, a dodatkowo miały miejsce w tym samym czasie, nakazuje pochylić się nad nimi z dużą wnikliwością. Celem niniejszego artykułu jest ukazanie wspólnych wątków znaczeniowych zawartych w przekazach obu wizji. Temu celowi ma służyć struktura wywodu, opierająca się na przybliżeniu najbardziej wyrazistych elementów przekazu werbalnego i wizualnego obu objawień. Wraz z ich syntezą zostanie też podjęta próba odczytania wspólnego celu działania Osób Trójcy Świętej objawiających się mistyczkom.

Chcąc zdefiniować naturę omawianych wizji, należałoby zacząć od tego, że Bóg najpełniej objawił się człowiekowi we Wcielonym Słowie, co umożliwia pojmowanie Bożego objawienia zarówno w kategoriach słowa, jak i obrazu. Urząd Nauczycielski Kościoła mówi, że po definitywnym przekazaniu objawienia Bożego przez Jezusa Chrystusa nie będzie żadnego nowego objawienia publicznego przed Jego powtórnym przyjściem u końca czasów ${ }^{3}$. Zdarza się jednak, że różne objawienia prywatne, które niczego nowego nie dodają do depozytu wiary i dlatego też do niego nie należą ${ }^{4}$, potrafią ożywić Kościól, o czym świadczy przypadek kultu miłosierdzia Bożego. Jak wiadomo, jedną z przyczyn rozszerzenia się tego kultu było zatwierdzenie w liturgii święta Miłosierdzia Bożego, co było spełnieniem jednego z żądań Jezusa, objawiającego się s. Faustynie.

2 Zob. E. E. Ravasio, Bóg Ojciec mówi do swoich dzieci, tłum. W. Kapica, Katowice 2017.

3 Por. Sobór Watykański II, konst. Dei Verbum, 4.

4 Por. Katechizm Kościoła Katolickiego, Poznań 1994, 67. 


\section{Czas upokorzeń i sprzeciwu}

Spełnienie niektórych żądań Jezusa z objawień s. Faustyny nie oznacza jeszcze, że kult będący ich efektem nie jest wciąż odbierany w kategoriach „skandalu miłosierdzia”. Po latach, jakie upłynęły od recepcji tego kultu, zdążyliśmy się w jakiejś mierze przyzwyczaić do jego radykalizmu i wydaje się on już nie budzić sprzeciwu - zarówno wśród wiernych, jak duchowieństwa, tak jak było to w czasach, kiedy zapiski mistycznego doświadczenia s. Faustyny trafiły w Kościele na indeks ksiąg zakazanych ${ }^{6}$. Zapoznając się z reakcją na treści zawarte w relacjach z przeżyć mistycznych obu wizjonerek, można mówić o podobnym charakterze sprzeciwu wobec tych przekazów, najczęściej płynących ze strony niektórych przedstawicieli władz kościelnych. Tak jak przed laty miał miejsce zakaz rozpowszechniania wszelkich przejawów kultu miłosierdzia Bożego, w pewnym momencie z podobnym zakazem musiała się zmagać również m. Eugenia. Zapisy jej wizji spotkały się z tak wielkim sprzeciwem, że nakazano je spalić oraz zakazano zakonnicy mówić o Bogu Ojcu i szerzyć Jego kult. Podobieństwa widoczne są również w upokorzeniach, jakich doznały obie wizjonerki.

W przypadku włoskiej zakonnicy należałoby mówić wręcz o jej prześladowaniu. Matka Eugenia zmuszona została do zrzeczenia się wszystkich funkcji zakonnych, w tym pełnienia posługi matki generalnej, łącznie z pozbawieniem jej habitu i pierścienia otrzymanego podczas ślubów wieczystych, co łączyło się również z wydaleniem jej poza mury klasztoru, w którym przez lata pełniła posługę. Do tego lakonicznego opisu jej bolesnych doświadczeń należy dołączyć absurdalne oskarżenia o wyłudzane pieniędzy oraz związany z tymi oskarżeniami pobyt w więzieniu, w większości czasu w izolatce. $\mathrm{Z}$ tymi danym jakże kontrastuje poniższy wykaz:

5 Por. G. Ryś, Skandal miłosierdzia, Kraków 2015.

6 Rozpowszechnianie kultu miłosierdzia Bożego przez dwadzieścia lat było zakazane na mocy dekretu wydanego przez Święte Oficjum, poprzednika Kongregacji Nauki i Wiary, datowanego na 19 listopada 1958 roku. 
W ciągu 12 lat działalności misyjnej [m. Eugenia] otworzyła niemal 70 ośrodków ze szpitalem, szkołą, kościołem - w najbardziej opuszczonych miejscach Afryki, Azji i Europy. Odkryła pierwsze lekarstwo przeciw trądowi [...], zachęciła do misji apostolskiej Raoula Follereau, który w oparciu o podwaliny przez nią położone został apostołem trędowatych. Zaprojektowała i zrealizowała w Azopté (Wybrzeże Kości Słoniowej) w latach 1939-41 „Miasto Trędowatych” - ogromne centrum przyjęć chorych, które nadal jest przodującym centrum w Afryce i na świecie ${ }^{7}$.

W dużej mierze znane są upokorzenia, jakich s. Faustyna doświadczała od sióstr ze swojego zgromadzenia, co zostało opisane w prowadzonym przez nią Dzienniczku ${ }^{8}$. Tym, co łączy losy obu zakonnic, jest świadomie pielęgnowana i wniesiona na wyżyny doskonałości heroiczna pokora, wynikająca z całkowitego poddawania się woli Boga na wzór Jezusa Chrystusa. Upokorzenia, jakich doznały obie siostry, były możliwe do udźwignięcia jedynie dzięki doświadczaniu niezwykłej bliskości ze strony Boga.

\section{Uznanie wiarygodności}

O ile przyczyny upokorzeń s. Faustyny upatrywać można m.in. w niemożności zaakceptowania przesłania płynącego z objawień, których ona doświadczała, o tyle w przypadku m. Eugenii należy się ich doszukiwać w niespotykanym w całym chrześcijaństwie przedmiocie objawień włoskiej zakonnicy. Jeśli bowiem ukazywanie się w objawieniach prywatnych Syna Bożego, Jego Matki Przenajświętszej, aniołów oraz wyniesionych na ołtarze świętych przyjmuje się w życiu Kościoła za coś oczywistego, to ukazywanie się Boga Ojca może budzić zrozumiałe zdziwienie, a nawet wywoływać sprzeciw, co zresztą miało miejsce wśród teologów w pierwszej fazie badań prawdziwości objawień m. Eugenii.

Odnośnie do powyższej kwestii znaczące jest świadectwo biskupa Grenoble Aleksandra Caillota, ordynariusza diecezji, w której miało

7 A. D’Ascanio (o. Andrea OFMCap), Wstęp, w: E. E. Ravasio, Bóg Ojciec mówi do swoich dzieci, dz. cyt., s. 4.

8 Por. F. Kowalska, Dzienniczek [dalej: Dzienniczek] 29, 128, 151, 710, 1648. 
miejsce objawienie, podsumowujące prace teologicznej komisji diecezjalnej badającej prawdziwość wizji m. Eugenii:

kiedy Siostra Eugenia oświadczyła, że miała objawienia Ojca, badający ją teologowie odparli jej, że objawienia Ojca są same w sobie niemożliwe i że jeszcze nigdy w historii nie miały miejsca. Obiekcjom tym Siostra oparła się, wyjaśniając po prostu: „Ojciec powiedział mi, żebym opisała to, co widziałam. On prosi swoich synów teologów, żeby szukali”".

Z dalszej relacji biskupa Caillota wynika, że teologowie istotnie znaleźli odpowiedzi na nurtujące ich wątpliwości:

To dopiero w styczniu 1934 roku teologowie odkryli u samego świętego Tomasza z Akwinu odpowiedź na zarzuty, które podnosili. Odpowiedź wielkiego Doktora dotycząca rozróżnienia między objawianiem się a misją była jasna. Pokonała przeszkodę, która paraliżowała cały proces. Wbrew uczonym teologom rację miała niewykształcona ignorantka. Jak po ludzku wytłumaczyć, także w tym przypadku, światło, mądrość i wytrwałość Siostry ${ }^{10}$

Nie wnikając $\mathrm{w}$ niuanse dogmatycznych wielowymiarowości, należy stwierdzić, że istnieją mocne podstawy do uznania orędzia Boga Ojca przekazanego za pośrednictwem $\mathrm{m}$. Eugenii za w pełni wiarygodne. Objawienie zostało uznane przez biskupa Caillota po ogłoszeniu pozytywnego werdyktu powołanej przez niego diecezjalnej komisji teologicznej, która rozpoczęła prace w 1934 roku, a zakończyła je po dziesięciu latach analiz. Dodać należy, że pojawiające się wówczas wątpliwości dotyczące prawdziwości objawień m. Eugenii zostały przezwyciężone orzeczeniem zarówno potwierdzającym „niepodważalność cnót m. Eugenii”, jak i uznającym za prawdziwy „przedmiot misji [objawienia]"11.

Odnośnie do objawień s. Faustyny, jest ogólnie znaną sprawą, że ich wiarygodność została potwierdzona oświadczeniem wydanym w 1978 roku przez Kongregację Nauki Wiary, która tym samym wycofała wcześniejsze zastrzeżenia, wysuwane w stosunku do pism s. Faustyny przez Kongregację Świętego Oficjum.

\footnotetext{
E. E. Ravasio, Bóg Ojciec mówi do swoich dzieci, dz. cyt., s. 10.

E. E. Ravasio, Bóg Ojciec mówi do swoich dzieci, dz. cyt., s. 10.

11 Por. E. E. Ravasio, Bóg Ojciec mówi do swoich dzieci, dz. cyt., s. 5-7.
} 


\section{Zbieżność treści objawień}

Analiza znaczeniowa orędzia Boga Ojca przekazanego za pośrednictwem m. Eugenii nie pozostawia wątpliwości, że w przypadku tych objawień mamy do czynienia z wydarzeniem absolutnie unikatowym i bezprecedensowym. W warstwie znaczeniowej, podobnie jak w przypadku orędzia miłosierdzia Bożego przekazanego za pośrednictwem s. Faustyny, jest ono ogłoszeniem prawd wiary, które częściowo uległy zapomnieniu albo są ukazywane w Kościele w niewystarczającym wymiarze. Objawiający się m. Eugenii Bóg Ojciec mówi o tym wprost:

Większość ludzi zna te wszystkie wydarzenia, ale ignoruje istotę rzeczy, to, że Miłość wszystkim kierowała! Tak, to jest Miłość, Ona jest tym, na co pragnę wam zwrócić uwagę. Teraz jednak ta Miłość jest zapomniana. Pragnę ją wam przypomnieć, abyście nauczyli się poznawać Mnie takim, jaki jestem ${ }^{12}$.

Zastanawia zbieżność treści zawartych w orędziach Boga Ojca oraz Jezusa Chrystusa, objawionych obu zakonnicom. W przypadku objawień s. Faustyny czas ich trwania był znacznie dłuższy od objawień m. Eugenii i wynosił kilkanaście lat. Miały one swój początek w osiemnastym roku jej życia, kiedy święta otrzymała powołanie do wstąpienia do Zgromadzenia Matki Bożej Miłosierdzia, i trwały aż do jej śmierci w 1938 roku. Z kolei m. Eugenia doznawała objawień jedynie przez kilka tygodni, latem 1932 roku, podczas pobytu w nowicjacie Zgromadzenia Sióstr Matki Bożej Apostołów. Zbieżność treści ujawnia się m.in. w ukazywaniu przymiotu miłosierdzia. W obu objawieniach wspólny jest także postulat sformułowany przez objawiające się Osoby, by zwracać się do Nich z ufnością. Zatrzymajmy się przy zagadnieniu ufności, które jest pojęciem kluczowym dla kultu miłosierdzia Bożego i warunkiem koniecznym otrzymania łask ze strony Boga. Jezus ukazujący się Faustynie wyraża to wprost: „Nie znajdzie ludzkość uspokojenia, dopóki się nie zwróci z ufnością do miłosierdzia mojego" ${ }^{13}$. Na konieczność ufności w kulcie miłosierdzia Bożego zwracali wielokrotnie uwagę zarówno spowiednik św. Faustyny

12 E. E. Ravasio, Bóg Ojciec mówi do swoich dzieci, dz. cyt., s. 16.

13 Dzienniczek 300. 
i propagator tego kultu, błogosławiony ks. Michał Sopoćko, jak również interpretatorzy ich dzieła: „Przez ufność składa się hołd Miłosierdziu Bożemu, bowiem spodziewając się pomocy od Boga, człowiek wyznaje, że on jest miłosierny i zawsze gotowy, by się udzielać"14. Chociaż powyższe słowa są komentarzem do objawień s. Faustyny, to w równym stopniu można by je zastosować do wypowiedzi zanotowanej w 1932 roku przez m. Eugenię: „Wzywajcie mnie imieniem Ojca z ufnością i miłością, a wszystko otrzymacie od tego Ojca, doznając równocześnie miłości i miłosierdzia" ${ }^{15}$.

Istnieją takie epizody doświadczeń mistycznych obu wizjonerek, które (nie znając szczegółowo ich pism) można by bez trudu przypisać każdej z nich. W obu przekazach oczywiście inaczej rozłożone są akcenty dotyczące ról Osób Boskich w udzielaniu się człowiekowi, co jest w pełni zgodne z wiedzą na ten temat, którą czerpiemy z analizy tekstów biblijnych. Odwoływanie się do mało znanych epizodów doświadczeń mistycznych mówiących o miłosierdziu, które zawarte są w objawieniach m. Eugenii, może jednak budzić zdziwienie. Przyzwyczailiśmy się już bowiem do tego, że głoszenie w naszych czasach treści miłosierdzia Bożego wiąże się na ogół wyłącznie z objawieniami s. Faustyny, ale również w objawieniach polskiej zakonnicy odnaleźć można wątki ukazywań się Boga Ojca, które z kolei zazwyczaj łączy się z objawieniami m. Eugenii. W Dzienniczku s. Faustyny można spotkać się ze znaczącym przykładem wizji z 1933 roku, podczas której ukazana jej została Pierwsza Osoby Trójcy:

Pod koniec litanii ujrzałam jasność wielką i w niej Boga Ojca. Przed jasnością tą a ziemią ujrzałam Jezusa przybitego do krzyża, i tak, że Bóg, chcąc spojrzeć na ziemię, musiał patrzeć przez rany Jezusa ${ }^{16}$.

Tego typu przykładów w zapiskach s. Faustyny jest więcej, a wspomnieć należy również o kwestii najbardziej spektakularnej dla samego kultu. Koronka do miłosierdzia Bożego ofiarowywana jest Bogu Ojcu

14 K. Szałkowska (s. Teresa ZSJM), Tajemnica Miłosierdzia. Stulecie urodzin św. Faustyny Kowalskiej, Warszawa 2005, s. 121.

15 E. E. Ravasio, Bóg Ojciec mówi do swoich dzieci, dz. cyt., s. 20.

16 Dzienniczek 59-60. 
i do Niego adresowana. W odróżnieniu od objawienia m. Eugenii symptomatyczne dla wizji s. Faustyny było jednak to, że podczas ich trwania, ze strony Boga Ojca nie padło ani jedno słowo. Włoska zakonnica doświadczyła natomiast ukazywań Boga Ojca, który w trakcie objawień w bardzo subtelny i jednocześnie konkretny sposób komunikował jej swoją wolę. Oto jeden z przykładów takiej wizji:

Proszę cię, byś spędzała dni w wielkim skupieniu, aby to dzieło, którego pragnę dokonać wśród ludzi, mogło rozprzestrzeniać się we wszystkich narodach możliwie najszybciej i aby ci, którzy będą obarczeni rozpowszechnianiem go, nie popełnili najmniejszej nieostrożności ${ }^{17}$.

Doświadczenie mistyczne m. Eugenii oparte jest właśnie na takim bezpośrednim kontakcie z Bogiem Ojcem, podobnie jak w przypadku s. Faustyny analogiczną relacją była bliska i intymna więź z Jezusem. Nadmienić należy, że w obu przypadkach Osoby Boskie za pośrednictwem zakonnic domagały się spełnienia pewnych żądań. W przypadku objawienia s. Faustyny wypełniona została już wola Jezusa, by pierwszą niedzielę po Wielkanocy ogłosić Świętem Miłosierdzia Bożego. Natomiast niezrealizowanym pragnieniem Boga Ojca jest ustanowienie osobnego święta zadedykowanego Pierwszej Osobie Trójcy. Wyrażone to zostało w następujący sposób:

Pragnę, żeby jeden dzień lub przynajmniej jedna niedziela była poświęcona dla uczczenia Mnie w szczególny sposób pod imieniem Ojca całej ludzkości. Chciałbym, aby to święto miało własną Mszę i oficjum ${ }^{18}$.

Jak dotąd nic nie zwiastuje szybkiego zajęcia się tym zagadnieniem przez Kongregację Kultu Bożego i Dyscypliny Sakramentów czy przez instytucję kardynalatu. Spośród grona kardynałów tematem niewystarczającej czci należnej Bogu Ojcu zainteresował się bodajże jedynie Jean Daniélou SJ (zanim przyjął godność kardynalską). Na ogół uważa się, że jego wypowiedź na ten temat była zainspirowana właśnie przesłaniem Boga Ojca z objawień m. Eugenii:

17 E. E. Ravasio, Bóg Ojciec mówi do swoich dzieci, dz. cyt., s. 21.

18 E. E. Ravasio, Bóg Ojciec mówi do swoich dzieci, dz. cyt., s. 25. 
Można powiedzieć, że daleko jeszcze jesteśmy od zrozumienia, co oznacza nieskończona czułość ojcowskiego serca Boga, i zapewne nie potrafimy się wznieść, w obliczu Trójcy Świętej, aż ku pierwotnemu źródłu, którym jest boskie ojcostwo ${ }^{19}$.

\section{Kontrowersje związane z wizualnym aspektem objawień}

Opisując zbieżności objawień obu mistyczek, należy również scharakteryzować ich wizualną stronę, zwłaszcza że w tym zakresie istnieje wiele cech wspólnych, co uwidacznia się już na poziomie nakazów ze strony objawiających się im Osób dotyczących namalowania obrazów. Jest symptomatyczne, że dwie Osoby Trójcy ukazane w ich wizjach: Ojciec lub Syn, domagają się od zakonnic namalowania obrazów będących wizualizacją przedmiotu objawień. W przypadku s. Faustyny już pierwsza wizja obrazu Jezusa Chrystusa według Jego woli miała być wzorem do wykonania obrazu wprowadzonego do kultu. Wizja ta miała miejsce zimą 1931 roku, co zdarzyło się cztery i pół roku wcześniej, zanim Pan Jezus podyktował jej koronkę do miłosierdzia Bożego. Siostra opisuje to w następujących słowach:

Wieczorem, kiedy byłam w celi, ujrzałam Pana Jezusa ubranego w szacie białej. Jedna ręka wzniesiona do błogosławieństwa, a druga dotykała szaty na piersiach. Z uchylenia szaty na piersiach wychodziły dwa wielkie promienie, jeden czerwony, a drugi blady ${ }^{20}$.

Obraz taki powstał dopiero po czterech latach od opisanej wizji i został namalowany w Wilnie przez Eugeniusza Kazimirowskiego dzięki zaangażowaniu się w to dzieło ks. Sopoćki.

Godne odnotowania jest to, że ukazywania się Jezusa s. Faustynie już po namalowaniu obrazu miały taką postać, jak ukazuje owo pierwsze wileńskie przedstawienie. A czy sam Jezus interesował się tym gotowym już obrazem, czy go zaaprobował? Jezus podczas objawień kilkakrotnie wypowiadał się na temat prototypowego obrazu, mówiąc, że domaga się

19 K. Osuch, Zawierzeni Bogu Ojcu, http://mateusz.pl/mt/ko/Krzysztof-Osuch-SJ-Rok2012-Zawierzeni-Bogu-Ojcu.htm (16.11.2017).

20 Dzienniczek 47. 
czci przez „ten obraz, który jest namalowany”, zaś s. Faustyna wielokrotnie odnotowywała w Dzienniczku, że widziała ,Jezusa w postaci, jako jest na tym obrazie"21.

Wzorzec obrazów został w jasny i przejrzysty sposób scharakteryzowany w zapiskach s. Faustyny oraz w Dzienniku błogosławionego Michała. Sporo informacji na ten temat dostarczają również przekazy s. Faustyny znane ks. Sopoćce oraz poufnym powiernikom jego misji szerzenia kul$\mathrm{tu}^{22}$, podobnie jak sama analiza obrazu prototypowego ${ }^{23}$. Wiele światła na to zagadnienie rzucają także świadectwa czci, jaką obraz ten odbierał przed II wojną światową. Dodać należy, że aż do momentu namalowania kolejnych obrazów, które niestety nie uwzględniają wielu wskazówek z wizji św. Faustyny, wizualne aspekty kultu miłosierdzia Bożego nie wzbudzały większych kontrowersji. Problemy pojawiły się w momencie niefortunnego zaakceptowania przez władze kościelne obrazów podszywających się pod wzór z objawień świętej. Nieporozumienia z tym związane mają też swoje źródło w opacznym interpretowaniu słów Jezusa z Dzienniczka: „Nie w piękności farby ani pędzla jest wielkość tego obrazu, ale w łasce mojej" ${ }^{24}$, które przez krytyków obrazu prototypowego, wskazujących na konieczność czci innych obrazów, miałyby uzasadniać błędne ujęcia samozwańczych realizacji. Wiele osób cytujących te właśnie słowa Jezusa nie ma zapewne świadomości, że dotyczą one sytuacji, która wydarzyła się na dwa miesiące przed ukończeniem obrazu ${ }^{25}$. Warto sobie też uświadomić, że po usłyszeniu tych słów sama twarz Jezusa była

21 Dzienniczek 87; por. Dzienniczek 437, 473, 499, 675, 1047, 1565.

22 Szereg informacji na ten temat jest znanych księżom marianom Niepokalanego Poczęcia NMP ze Stockbridge (USA), którzy mają ogromne zasługi w rozpowszechnianiu kultu miłosierdzia Bożego na całym świecie. Dzięki ich dziełu kult ten zaczął się rozpowszechniać począwszy od lat czterdziestych XX wieku.

${ }^{23}$ Więcej na ten temat w mojej książce: Tajemnica widzialności Boga, Kraków 2015, s. $125-155$.

24 Dzienniczek 313.

${ }^{25}$ Fakt ten jest doskonale znany w Zgromadzeniu Sióstr Jezusa Miłosiernego założonym przez ks. Sopoćkę. W Kalendarium życia siostry Faustyny zamieszczanym w Dzienniczku we wszystkich znanych mi wydaniach (na różnych stronach) jest nieprawdziwa informacja: „Ukończony został obraz Miłosierdzia Bożego. Siostra Faustyna płacze, że Pan Jezus nie jest tak piękny, jak Go widziała”. Powinno być: „na dwa miesiące przed ukończeniem obrazu siostra Faustyna płacze...". 
przynajmniej kilkunastokrotnie przemalowywana na wyraźne żądanie s. Faustyny, co działo się aż do momentu, kiedy ostatnia wersja obrazu zyskała wyraźną aprobatę Jezusa podczas trwających cały czas objawieńn ${ }^{26}$.

Ksiądz Sopoćko wielokrotnie zwracał uwagę na ignorowanie słów Jezusa dotyczących obrazu z objawień św. Faustyny ${ }^{27}$. Tymczasem pomijanie tego właśnie aspektu wizji polskiej zakonnicy nie może pozostać bez wpływu na recepcję treści przesłania miłosierdzia Bożego, ponieważ treść przekazu werbalnego tych objawień została dopełniona treścią przekazu zawartego we wzorcu wizualnym. Należy sobie też uświadomić, że w kulcie miłosierdzia Bożego miejsce obrazu jest szczególne. Nie pełni on bowiem w nim jedynie funkcji wizualizacji słów modlitwy, nie jest jakimś estetycznym ozdobnikiem czy dodatkiem do tego kultu, lecz jest jego autonomicznym medium, równoprawnym ze słowem. Dzięki objawieniu poprzez obraz, które w pełni harmonizuje z objawieniem poprzez słowo, prawda o miłosiernej miłości Ojca zostaje w ten sposób wzmocnio$\mathrm{na}^{28}$. Niestety w wielu przedstawieniach będących wyrazem religijności ludowej, które mają tylko luźne powiązania z objawieniami s. Faustyny, niektóre wątki tego objawienia nie zostały po prostu ujęte, dlatego też uwłaczają orędziu Jezusa z jej objawień i samemu kultowi. Nie należy więc się dziwić, że kwestia trywializacji kultu miłosierdzia Bożego cały czas budzi uzasadniony sprzeciw ze strony tych środowisk w Kościele, które w swojej praktyce uwzględniają pełny zakres orędzia Jezusa z objawień polskiej zakonnicy.

W przypadku wizualnego aspektu objawień $\mathrm{m}$. Eugenii również można spotkać się z różnego typu kontrowersjami. Pojawiają się one głównie ze względu na przedmiot wizji oraz polecenie wykonania obrazu ukazującego Pierwszą Osobę Trójcy i wprowadzenia go do kultu. Owe

26 Taką informację uzyskałem od ks. Serafima Michalenki ze Stockbridge, wicepostulatora na USA w procesie kanonizacyjnym św. Faustyny Kowalskiej. Do myślenia daje również istnienie cech twarzy Chrystusa z obrazu Kazimirowskiego, które wykazują całkowitą zbieżność z analogicznymi cechami twarzy Chrystusa z Całunu Turyńskiego. Niezwykłą zgodność tych cech wykazał m.in. wspomniany wyżej ks. Serafim Michalenko.

27 Por. M. Sopoćko, Dziennik, Białystok 2010, s. 123-136.

28 Ponownie odwołuję się do myśli zawartej w mojej książce, Tajemnica widzialności Boga, dz. cyt., s. 118. 
kontrowersje biorą się po części zapewne stąd, że objawienia m. Eugenii wydają się iść dalej aniżeli ustalenia Soboru Nicejskiego II dotyczące obrazu i jego miejsca w kulcie. Podczas tego soboru ojcowie stwierdzili, że

przedmiotem kultu powinny być nie tylko wizerunki drogocennego i ożywiającego Krzyża, lecz tak samo czcigodne i święte obrazy [...] naszego Pana Jezusa Chrystusa, Boga i Zbawiciela, Niepokalanej Pani naszej, Świętej Bożej Rodzicielki, godnych czci Aniołów oraz wszystkich świętych i świątobliwych mężów ${ }^{29}$.

Znana jest wprawdzie wypowiedź św. Jana Damasceńskiego na ten temat, która w kontekście objawień m. Eugenii otwiera furtkę do tego, by włączyć do tego grona również Osobę Boga Ojca: „Gdy Niewidoczny, przybierając postać cielesną, stanie się postrzegalny, wówczas uczyń podobiznę Tego, który się ukaże"30, tym niemniej kontekst całej wypowiedzi ostatniego ojca epoki patrystycznej wyraźnie wskazuje na fakt, że teologowi chodziło o Drugą Osobę Trójcy. Furtka ta jednak została uchylona, co pozwala przyjąć, że z punktu widzenia doktryny wiary wykonanie obrazu Boga Ojca ukazanego pod postacią człowieka i oddawanie mu czci jest dopuszczalne i godziwe. Zresztą w zachodniej tradycji ikonograficznej od czasów renesansu tworzenie wizerunków Boga Ojca jest na porządku dziennym, co czyni się zazwyczaj w scenach ukazujących Trójcę Świętą, żeby wspomnieć tylko o najbardziej znanej spośród nich, autorstwa Masaccia, z kościoła Santa Maria Novella we Florencji ${ }^{31}$. Również w tradycji wschodniej Kościoła czyniło się takie próby, szczególnie od osiemnastego stulecia, co nie zawsze spotykało się z aprobatą wybitnych teologów ikony ${ }^{32}$. W związku z tym, że podobnego rodzaju wizje pojawiały się w starotestamentowych literackich obrazach skomponowanych z opisów o takich właśnie antropomorficznych cechach, należałoby zadać pytanie, dlaczego takim scenom odmawiać racji istnienia w obszarze wizualności?

29 Sobór Nicejski II, Dekret wiary, 14-15, w: Dokumenty Soborów Powszechnych: tekst grecki, łaciński, polski, t. 1, red. A. Baron, H. Pietras, tłum. T. Wnętrzak, Kraków 2002, s. 337.

3o Cytuję za: L. Uspienski, Teologia ikony, tłum. M. Żurowska, Poznań 1993, s. 16.

31 Więcej na ten temat w: Tajemnica widzialności Boga, dz. cyt., s. 62-74.

32 Leonid Uspienski taki proceder określa jako „uchybienie”. Por. L. Uspienski, Teologia ikony, dz. cyt., s. 123. 
Zasadniczym motywem odmawiania im racji istnienia w obszarze wizualności byłoby uznanie, że wyobrażony na ludzki sposób obraz Boga Ojca nie umożliwia dostrzeżenia w nim Jego bóstwa, a w takim przypadku straciłoby rację bytu ukazywanie takiego obrazu, przynajmniej w liturgii. Należałoby jednak dodać, że również w przypadku przedstawień Jezusa Chrystusa nie jest możliwe uchwycenie Jego bóstwa, które „wykracza ponad wszelką możliwość bycia przedstawionym”" ${ }^{33}$. Jeśli jednak na soborze nicejskim II w odniesieniu do Drugiej Osoby Trójcy wykazano, że możliwe jest odczytywanie boskości Chrystusa w Jego człowieczeństwie, bo Jego wizerunek wskazuje na całego Chrystusa jako osobę, to wydaje się, że również prawo to może mieć zastosowanie w odniesieniu do ukazywania wizerunków Pierwszej Osoby Trójcy.

Pomimo istnienia opisanych kontrowersji objawień m. Eugenii w ich aspekcie wizualnym, prawdziwość jej wizji została uznana na szczeblu diecezjalnym już po około dziesięciu latach od zakończenia objawień. W ocenie komisji teologicznej badającej prawdziwość wizji zaważył oczywiście fakt, że objawienia m. Eugenii są zgodne z doktryną wiary, z objawieniem biblijnym i z duchem Tradycji. Chcąc ocenić ortodoksyjność wizualnych aspektów tego objawienia, pozostaje zapoznać się z relacją samej wizjonerki. Włoska zakonnica doświadczyła wizji Boga Ojca latem 1932 roku. Matka Eugenia nie sprecyzowała, w jaki sposób Bóg Ojciec ukazał się jej, kiedy ujawnił już swoją obecność. Jej świadectwo ma charakter opisowy od momentu, kiedy Bóg Ojciec, jak to określa sama zakonnica, „odłożył chwałę”:

Po przyjęciu postawy zwyczajnego człowieka - złożywszy koronę i chwałę u swych stóp - położył kulę ziemską na swym Sercu, podtrzymując ją lewą ręką. Następnie usiadł obok mnie. [...] W moim nieuctwie nie znajduję słów, aby wyrazić to, co Bóg dał mi do zrozumienia ${ }^{34}$.

Odmiennie niż w przypadku wizji s. Faustyny, podczas której otrzymała ona polecenie wykonania obrazu ukazującego się jej Jezusa według

33 M. Pyc, Tajemnica Jezusa Chrystusa $w$ definicji wiary Soboru Nicejskiego II, „Studia Gnesnensia" 25 (2011), s. 222.

34 E. E. Ravasio, Bóg Ojciec mówi do swoich dzieci, dz. cyt., s. 12. 
bardzo konkretnego wzoru, Bóg Ojciec nie zobowiązał m. Eugenii, by wykonała Jego wizerunek według jakichś ścisłych wskazówek, z wyjątkiem jednej bardzo istotnej sugestii, korygującej dotychczasowy sposób ukazywania Boga Ojca pod postacią starca:

Nie wierzcie, że jestem owym strasznym starcem, którego ludzie przedstawiają na swoich obrazach i w swoich książkach! Nie, nie, nie jestem ani „młodszy” ani „starszy” od Mojego Syna i Mego Ducha Świętego! ${ }^{35}$

Pokłosiem tej wizji jest kilka obrazów ukazujących Boga Ojca pod postacią młodego mężczyzny, spośród których najbardziej rozpowszechnione są dwa przedstawienia. Pierwsze z nich zostało wykonane jeszcze w latach trzydziestych ubiegłego stulecia przez nieznanego autora, na podstawie opisu m. Eugenii - tak podają źródła nie w pełni udokumentowane ${ }^{36}$. Kolejne namalowała w latach dziewięćdziesiątych $\mathrm{w}$ formie ikony włoska ikonopisarka Lia Gladiolo.

Jej realizacja, choć może budzić wątpliwości co do sposobu odzwierciedlenia twarzy Boga Ojca ukazanego pod postacią człowieka (co samo w sobie jest ogromnym wyzwaniem dla wykonawcy obrazu), uwzględnia wszystkie zasadnicze wątki z opisu m. Eugenii oraz duchowe treści objawienia. Właśnie zapewne z tego powodu obraz Gladiolo budzi kontrowersje, ponieważ u niektórych odbiorców burzy „strefę komfortu” wytworzoną w związku z obecnością w życiu Kościoła chybionych wzorców ikonograficznych, które stoją w opozycji do treści orędzia Boga Ojca. Jak bardzo owa niefortunna „strefa komfortu”, zawładnęła wiernymi Kościoła, świadczyć może jedna z ekspertyz (być może jedyna) obrazu Gladiolo. Wytknięto w niej brak ortodoksyjności obrazu włoskiej ikonopisarki, który zdaniem autorki ekspertyzy wynika m.in. z niemożności wpisania go w ciągłość tradycji ikonograficznej ${ }^{37}$. Autorka, przyjmując stereotypowy i schematyczny model oceny dzieła malarskiego, nie wzięła

35 E. E. Ravasio, Bóg Ojciec mówi do swoich dzieci, dz. cyt., s. 23.

36 Por. https://commons.wikimedia.org/wiki/File:Obraz_Boga_Ojca.jpg (20.11.2017).

37 W ekspertyzie zawarto oparte na fałszywych przesłankach chybione wnioski, dlatego też autorka traktuje "chęć włączenia go [obrazu] do kultu” jako „spore nieporozumienie”. Zob. Z. Bator, Współczesna ikona Boga Ojca. Nowatorstwo czy herezja?, „Teologia w Polsce” 9 (2015) nr 1, s. 97-108. 
pod uwagę tego, że jeden z zasadniczych nurtów tej tradycji, mający swoje źródło w zwrocie ikonicznym, jaki miał miejsce kilkaset lat temu, stał się przyczyną kryzysu obrazu w Kościele ${ }^{38}$. Jego bezpośrednią przyczyną była rezygnacja z wymiaru duchowego na rzecz powierzchownego ilustratorstwa. Należałoby zadać pytanie, co powinno stanowić kryterium oceny obrazu Gladiolo: odwołanie się do nauczania Kościoła sięgającego czasów apostolskich czy powoływanie się na autorytet anachronicznej tradycji ikonograficznej?

Ponieważ w dzisiejszych czasach przeciętnemu uczestnikowi nabożeństw w rzymskokatolickich świątyniach z wielką trudnością przychodzi odróżnienie rzeczywistej wartości dzieł otwierających na misterium od fatalnych wizualnych realizacji bezmyślnie powielających wzorce, które nie mają najmniejszego uzasadnienia w duchowości obrazu, nie należy się dziwić, że wokół zjawisk wizualnych mających źródło w prywatnych objawieniach powstaje tak wiele kontrowersji ${ }^{39}$. Trzymając się ducha objawień m. Eugenii, należałoby jednak stwierdzić, że dobrze się stało, iż w naszych czasach podjęte zostało wezwanie Boga Ojca zjej wizji, by wykonać obraz, który zrywa z tradycją ukazywania Go pod postacią starca. Trafną decyzją autorki obrazu z lat dziewięćdziesiątych ubiegłego stulecia jest niewątpliwie odwołanie się do estetycznych wzorców ikonicznych, które pozwalają postrzegać postać Boga Ojca w kategoriach ponadczasowych. Należałoby rozważyć, czy również w przypadku tworzenia nowych obrazów Jezusa Miłosiernego nie należałoby odwoływać się do analogicznych wzorców. Byłoby to uzasadnione, patrząc nie tylko z perspektywy estetycznej. Znaczące wydaje się, że jeden z cudów koniecznych do zakończenia procesu kanonizacyjnego s. Faustyny był związany właśnie z obrazem Jezusa Miłosiernego wykonanym w konwencji świętej ikony.

38 Więcej na ten temat w mojej książce: Obraz jako medium wtajemniczające $w$ misterium, Gdańsk 2017, s. 45-67.

${ }^{39}$ Osoby odpowiedzialne za kult w Kościele jak dotąd nie podjęły żadnych znaczących działań zmierzających do przeciwstawienia się negatywnym skutkom tej anachronicznej tradycji, nierzadko wypaczającej prawdy wiary przez utrwalanie wśród wiernych fałszywego obrazu Boga Ojca. 


\section{Aspekt celu objawień siostry Faustyny i matki Eugenii}

Przedstawione powyżej kontrowersje, choć w obu przypadkach dotyczą nieco odmiennych kwestii, mają wspólne przyczyny. Jedną z nich jest pominięcie ważnych treści podczas odczytywania przekazów pochodzących od dwóch Osób Trójcy z objawień zakonnic, co staje się czytelne, jeśli odwołamy się do istoty tych przekazów. Inną przyczyną jest pominięcie celów, które stoją za tymi treściami. Chociaż dopiero treść czyni przekaz czytelnym, to o wiele ważniejsze jest to, że przekaz, za którym stoi jakiś nadawca, ma zazwyczaj cel do osiągnięcia.

Odnośnie do objawienia s. Faustyny jednym z najbardziej czytelnych celów jest przypomnienie prawdy wiary o miłości miłosiernej Boga do człowieka. To cel, który został sformułowany wprost dzięki przekazowi werbalnemu. Przekaz wizualny dopełnia tę prawdę, a zostaje on skomentowany przez Jezusa w następujący sposób: „Podaję ludziom naczynie, z którym mają przychodzić po łaski do źródła miłosierdzia. Tym naczyniem jest ten obraz z podpisem: Jezu, ufam Tobie" ${ }^{40}$. Z kolei po przeanalizowaniu przekazu otrzymanego za pośrednictwem m. Eugenii, staje się czytelne, że jednym z celów tych objawień jest skorygowanie fałszywego obrazu Boga, który zadomowił się w Kościele. Również w tym przypadku przekaz wizualny dopełnia treści objawienia werbalnego, który także doczekał się komentarza, tym razem oczywiście ze strony objawiającego się Boga Ojca:

Chcę, aby widzialnym znakiem Mojej niewidzialnej obecności był obraz: niech ukazuje, że tam jestem, rzeczywiście obecny. [...] Niewątpliwie i teraz jestem wszędzie, ale chciałbym być przedstawiany w zauważalny i konkretny sposób! $!^{41}$

Wizualny przekaz Boga Ojca z wizji m. Eugenii, który zgodnie z Jego wolą powinien mieć swoją kontynuację w obrazie wprowadzonym do kultu, należałoby określić w sposób najbardziej syntetyczny jako nawiązujący do epifaniczno-uobecniającej koncepcji obrazu chrześcijańskiej tradycji ikonograficznej. Do tego sądu upoważnia myśl zawarta

41 E. E. Ravasio, Bóg Ojciec mówi do swoich dzieci, dz. cyt., s. 24. 
w powyższym przekazie, by obraz był „widzialnym znakiem [...] niewidzialnej obecności" Boga. W tym momencie ujawnia się również kolejny cel wizualnego przekazu z objawień włoskiej zakonnicy, którym nie ma być li tylko uczynienie obrazu Boga Ojca jako takiego, lecz uczynienie go w tym celu, by odbierać go w kategoriach znaku obecności i bliskości Boga.

Powyższe cele szczegółowe pozwalają uwidocznić niezdefiniowany jeszcze cel nadrzędny objawień obu zakonnic, który wydaje się wspólny, tak jak wspólne jest działanie Ojca i Syna (oczywiście także i Ducha), którzy są ze sobą w jedności. Tym celem jest doprowadzenie do zbawienia każdego człowieka powierzonego Synowi przez Ojca, co dokonuje się dzięki wierze rodzącej się w człowieku dzięki działaniu Ducha Świętego, będącej zatem wynikiem wspólnego i jednoczesnego działania Bożych Osób. To oczywiście echo nauki na temat roli Osób Boskich w udzielaniu się człowiekowi, która zawarta jest m.in. w Ewangelii według św. Jana. Zostało w niej scharakteryzowane działanie Syna jako będące równe działaniu Ojca i odsłaniające plan Ojca. W świetle charakterystyki wspólnego działania Bożych Osób zawartej przez Ewangelistę staje się czytelna rola człowieka zaproszonego do udziału w Bożej wspólnocie. Zasadniczo rola ta polega na oddawaniu czci w równym stopniu Ojcu i Synowi, co wyrażają słowa Jezusa: „aby wszyscy oddawali taką cześć Synowi, jaką oddają Ojcu" (J 5, 23). Powyższa myśl zostaje dopełniona w kolejnym zdaniu kategorycznym sądem Jezusa: „Kto nie czci Syna, ten nie czci także Ojca, który Go posłał".

W świetle powyższego nasuwa się następujące pytanie: czy dzisiaj cześć oddawana Ojcu dorównuje czci oddawanej Synowi? Staje się ono uzasadnione zwłaszcza w kontekście skargi Boga Ojca z objawień udzielonych m. Eugenii:

Nikt jeszcze nie zrozumiał bezmiernych pragnień Mego Serca Boga Ojca: pragnę być znanym, kochanym i czczonym przez wszystkich ludzi, sprawiedliwych i grzeszników. [...] Jednakże tej szczególnej czci - której tak bardzo pragnąłem i pragnę - dotąd Mi jeszcze nie okazano! ${ }^{42}$

42 E. E. Ravasio, Bóg Ojciec mówi do swoich dzieci, dz. cyt., s. 18. 
Jeśli nawet cześć oddawana Ojcu dorównuje czci oddawanej Synowi, to sądzę, że trzymając się ignacjanskiej dewizy: „Ad maiorem Dei gloriam”, należy pochylić się z większą niż dotąd wnikliwością nad przesłaniem płynącym z tego objawienia. Można to uczynić, powtarzając choćby przytoczone wyżej pytanie Boga Ojca, które skierował do tych, którzy są „obarczeni rozpowszechnianiem” Jego kultu: czy w tej materii nie została popełniona jakaś choćby „najmniejsza nieostrożność”?

\title{
Zakończenie
}

Jeśli jest uzasadnione przyjęcie, że przekazy zawarte w objawieniach s. Faustyny i m. Eugenii są zbieżne co do treści, natomiast jednoczesność tych objawień wskazuje na celowość działania Osób Trójcy Przenajświętszej, należałoby też uznać, że przed nami stoi ogromne wyzwanie, by zrealizować Ich wspólne cele. Jednym z nich jest ogłoszenie i obchodzenie świąt poświęconych Osobom objawiającym się obu zakonnicom. Święto Miłosierdzia Bożego, jak wiadomo, zostało już ogłoszone i jest obchodzone w Kościele, co zostało zapowiedziane w proroczej wizji s. Faustyny, zapisanej w formie dialogu, jaki święta prowadziła zJezusem:

\begin{abstract}
„Czego pragniesz, córko moja?” - I odpowiedziałam: Pragnę chwały i czci dla miłosierdzia Twojego. - „Cześć już odbieram przez założenie i obchodzenie święta tego; czego jeszcze pragniesz?" [...] Duch mój zatonął w Jego miłości, czuję, jakobym się rozpłynęła w Bogu i znikła w Nim. Kiedy przyszłam do siebie, głęboki spokój zalewał duszę moją, i udzieliło się umysłowi mojemu dziwne zrozumienie wielu rzeczy, które przedtem były mi niezrozumiałe ${ }^{43}$.
\end{abstract}

Czy spełni się wezwanie Boga Ojca z objawień m. Eugenii, by ogłosić w Kościele święto Jemu poświęcone, zależy od tego, na ile poważnie potraktujemy Boże natchnienia do szukania większej Jego chwały. Nie mam wątpliwości, że kierując się „zmysłem wiary”, nie czekając na oficjalne ogłoszenie Święta Boga Ojca, należy je tak czy inaczej obchodzić, zgodnie ze wskazaniami orędzia spisanego przez włoską zakonnicę, znanego pod tytułem: Bóg Ojciec mówi do swoich dzieci, które już kilkadziesiąt lat temu

43 Dzienniczek 1048. 
zyskało aprobatę biskupa Caillota, ordynariusza diecezji, w której miało miejsce objawienie. Pamiętać należy, że w historii Kościoła kierowanie się przez wiernych zasadą „zmysłu wiary” niejednokrotnie przynosiło już zbawienne owoce. 


\section{Summary}

O zbieżnościach przekazów w objawieniach siostry Faustyny Kowalskiej i matki Eugenii Elisabetty Ravasio

W niniejszym artykule dokonuje się konfrontacji objawień prywatnych s. Faustyny Kowalskiej oraz m. Eugenii Elisabetty Ravasio. Ich przedmiotem były dwie Osoby Trójcy Świętej: Bóg Ojciec oraz Jezus Chrystus. Autor ukazuje wspólne wątki znaczeniowe zawarte $\mathrm{w}$ przekazach pochodzących $\mathrm{z}$ obu objawień oraz analizuje strukturę wizji obu zakonnic. Zdaniem autora ich cechą charakterystyczną jest rzadko spotykane w historii objawień prywatnych połączenie poznania pojęciowego z poznaniem obrazowym. W ramach analizy sfery znaczeniowej zostaje też podjęta próba odczytania wspólnego celu działania Osób Trójcy Świętej objawionych mistyczkom.

Słowa kluczowe: wizja mistyczna, zbieżność, przekaz wizualny, poznanie obrazowe, aspekt celu

\section{On the Convergence of Messages in the Apparitions of Sister Faustina Kowalska and Mother Eugenia Elisabetta Ravasio}

This article confronts the private revelations of sister Faustyna Kowalska and mother Eugenia Elisabetta Ravasio. Their subject was two persons of the Holy Trinity: God the Father and Jesus Christ. The author shows the common threads of meaning contained in communications from both revelations and analyses the structure of the vision of the two nuns. According to the author, their characteristic feature is a combination of conceptual cognition and visual cognition, rarely seen in the history of private revelations. As part of the analysis of the sphere of meaning, an attempt is also made to read the common purpose of the activities of the persons of the Holy Trinity revealed to the mystics.

Keywords: mystical vision, convergence, visual message, pictorial cognition, aspect of the goal

\section{Bibliografia}

Bator Z., Współczesna ikona Boga Ojca. Nowatorstwo czy herezja?, „Teologia w Polsce” 9 (2015) nr 1, s. 97-108.

Evdokimov P., Sztuka ikony, teologia piękna, tłum. M. Żurowska, Warszawa 1999. Jan Paweł II, Encyklika Dives in misricordia.

Jan Paweł II, List do artystów. 
Kasper W., Miłosierdzie. Klucz do chrześcijańskiego życia, tłum. R. Zajączkowski, Poznań 2014.

Katechizm Kościoła Katolickiego, Poznań 1994.

Kowalska F., Dzienniczek, Warszawa 1999.

Michalenko S., Devotion to the Divine Mercy, Goa 1984.

Łukaszuk T., Ikona w życiu, w wierze i w teologii Kościoła, Kraków 2008.

Osuch K., Zawierzeni Bogu Ojcu, http://mateusz.pl/mt/ko/Krzysztof-Osuch-SJ-Rok2012-Zawierzeni-Bogu-Ojcu.htm (16.11.2017).

Pyc M., Tajemnica Jezusa Chrystusa $w$ definicji wiary Soboru Nicejskiego II, „Studia Gnesnensia" 25 (2011), s. 206-224.

Quenot M., Ikona okno ku wieczności, tłum. H. Paprocki, Białystok 1997.

Ratzinger J., Duch liturgii, tłum. E. Pieciul, Poznań 2002.

Ravasio E. E., Bóg Ojciec mówi do swoich dzieci, tłum. W. Kapica, Katowice 2017.

Ryś G., Skandal mitosierdzia, Kraków 2015.

Schönborn Ch., Ikona Chrystusa, tłum. W. Szymona, Poznań 2001.

Sobór Watykański II, Konstytucja Dei Verbum, w: Sobór Watykański II, Konstytucje, Dekrety, Deklaracje, Poznań 1968, s. 350-363.

Sopoćko M., Dziennik, Białystok 2010.

Szałkowska K. (s. Teresa ZSJM), Tajemnica Miłosierdzia. Stulecie urodzin św. Faustyny Kowalskiej, Warszawa 2005.

Uspienski L., Teologia ikony, tłum. M. Żurowska, Poznań 1993. 